\section{A burning candle in the dark night-incidental intradiploic epidermoid cyst of occipital bone}

\section{Sir,}

Ectodermal squamous epithelial cells, entrapped during neural tube closure between the $3^{\text {rd }}$ and $5^{\text {th }}$ weeks of gestation, form epidermoid cysts or congenital cholesteatomas. Epidermoid cysts compromise $0.2-1.8 \%$ of all intracranial tumors and are benign histologically. ${ }^{[1]}$ Intracranial locations for epidermoid cysts are cerebellopontine angle, parasellar region, middle cranial fossa, thalamus, corpus callosum, lateral ventricle, fourth ventricle, parietal lobe, occipital lobe, pineal region, brainstem, and intradiploic location. About $25 \%$ of all epidermoid cysts present in intradiploic location as expansible lesions, hence to our knowledge, incidental presentation as a soft swelling on occipital bone has been reported only twice in the scientific literature in English..$^{[1-4]}$ We present a young patient with an intradiploic epidermoid cyst presented as a soft swelling on occipital bone and discuss its etiology, histology, radiology, and management strategies. A 27-year-old man admitted to clinic with a history of softness and irregularity on the back of his head just behind his left ear. On physical examination, the mass lesion was soft, nonfluctuant, and nontender to palpation. The patient was neurologically stable. Lateral skull X-ray revealed a hypodense area of $24 \mathrm{~mm} \times 19 \mathrm{~mm} \times 20 \mathrm{~mm}$ size close to the left mastoid process [Figure 1a]. Magnetic resonance imaging (MRI) scans revealed the lesion to be present in the intradiploic space. The lesion was lobulated, and it was iso- to hyperintense on T1- and iso- to hypointense on T2-weighted scans compared to cerebrospinal fluid, respectively [Figure $1 \mathrm{~b}$ and $1 \mathrm{c}$ ]. On diffusion-weighted MRI, the lesion was hyperintense [Figure 1d]. Surgical

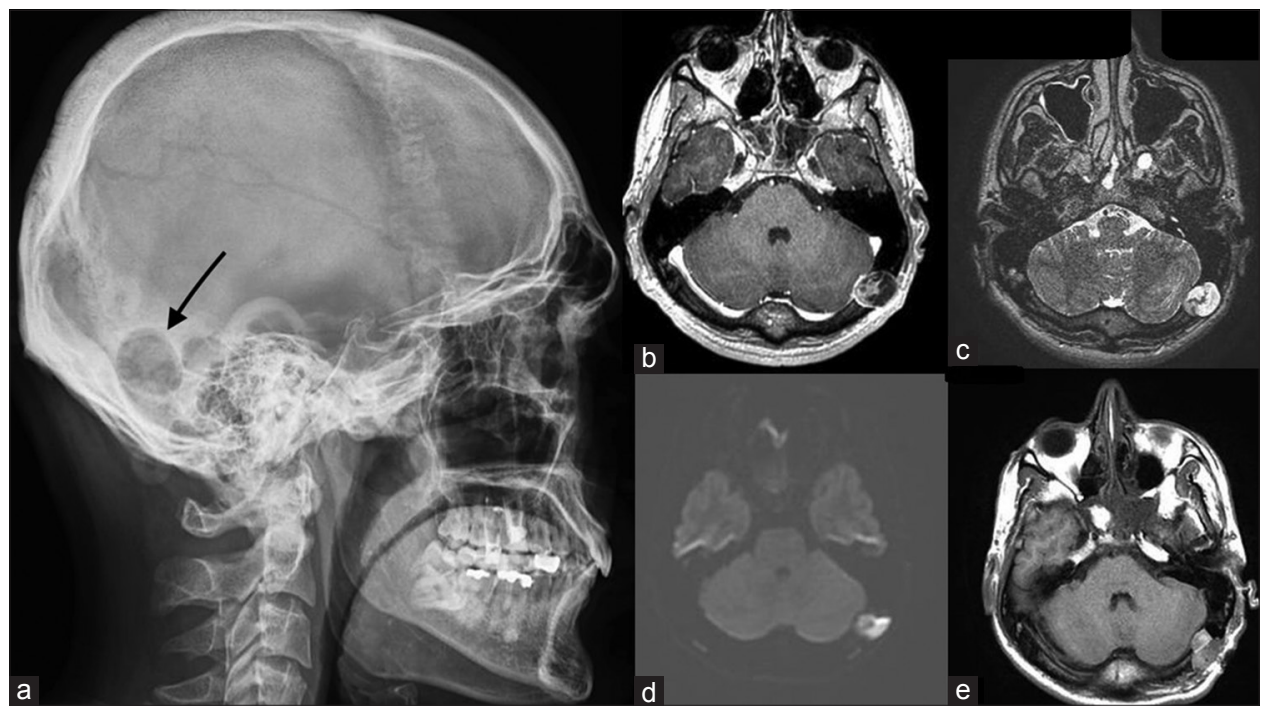

Figure 1: A hypodense zone is visible on the occipital bone close to mastoid process (a). A mass lesion, that is, iso- to hyperintense on T1- and iso- to hypointense on T2-weighted scans is visible in the intradiploic area of the left occipital bone (b and c). The lesion enhances on diffusionweighted magnetic resonance imaging (d). The cyst has been resected as en bloc (e) 
en bloc excision was managed through a paramedian linear-cut $5 \mathrm{~cm}$ incision [Figure 1e]. The contents of the cyst had a classical pearl-like appearance. Histopathological diagnosis was an epidermoid cyst. Postoperative course of the patient was uneventful. Epidermoid cysts mostly present laterally, compared to dermoid cysts, which was speculated to be due to migration of this malformed cystic tissue through developing neurovascular structures ${ }^{[1]}$ The deadline for epidermoid cysts to present as intra- or extra-parenchymal cysts in the brain has been determined by the time of neural tube closure, after which intradiploic variants appear. Computed tomography $(\mathrm{CT})$ and MRI are the best imaging modalities for intradiploic epidermoid cysts. While CT depicts lytic nature of the bone and possible calcifications in the cyst, MRI can make it recognizable with diffusion-weighted scans, especially for differentiation from intradiploic arachnoid cyst. ${ }^{[5]}$ However, still, routine sequences of $\mathrm{T} 1$ and $\mathrm{T} 2$ are required to make a differentiation between epidermoid and dermoid cysts. Dermoid cysts are hyperintense both on T1- and T2-weighted scans, whereas epidermoid cysts are usually hyperintense on T2-weighted MRI yet have variable intensity on T1-weighted MRI. ${ }^{[6]}$ The patient in our case was harboring a lobulated lesion in the occipital bone, and the lesion had a heterogeneous intensity on both T1- and T2-weighted MRI. Nevertheless, histopathological analysis can clarify the final diagnosis in case of conflict. Epidermoid cysts are benign in nature; however, some catastrophic events have been reported in literature. Ormond et al. and Gadgil et al. reported cases of intradiploic epidermoid cysts that presented as hemorrhagic mass lesions. ${ }^{[7,8]}$ One of the cysts was present in the orbita and was extending to the sphenoid bone, and the other one was in the frontotemporal bone. Both of them were impalpable and were incidentally diagnosed after mild headache, eye pain, and minor head trauma, respectively. Malignant transformations of intradiploic epidermoid cysts have also been described. ${ }^{[9,10]}$ Our patient admitted with only a soft swelling on his head, which turned to be an intradiploic epidermoid cyst. After talking with the patient, surgical resection was planned, accordingly. The cyst was excised en bloc from the occipital bone without any complication. Intradiploic epidermoid cysts usually present as expansible lesions on the skull. Guridi et al. and Kuzeyli et al. described the two cases of occipital intradiploic epidermoid cysts presented as soft swellings on the cranium. ${ }^{[3,4]}$ Despite the benign nature of intradiploic epidermoid cysts, surgery should be performed in suitable circumstances to prevent rare but possible catastrophic events or malignant transformations.

\section{Financial support and sponsorship}

Murat Şakir Ekşi, M.D. was supported by a grant from
Tubitak (The Scientific and Technological Research Council of Turkey), Grant number: 1059B191400255.

\section{Conflicts of interest}

There are no conflicts of interest.

$$
\begin{array}{r}
\text { Baran Yılmaz, Murat Şakir Ekşi }{ }^{1}, \text { Akın Akakın, } \\
\text { Türker Kılıç }
\end{array}
$$

Department of Neurosurgery, Bahçeşehir University Medical Faculty, Istanbul, Turkey, ${ }^{1}$ Department of Orthopaedic Surgery, Spine Center,

University of California at San Francisco, San Francisco, CA, USA

Address for correspondence: Dr. Murat Şakir EKŞi,

Department of Orthopaedic Surgery, University of California at San Francisco, 500 Parnassus Avenue MU320 West, San Francisco, CA 94143-0728, USA. E-mail: muratsakireksi@gmail.com

\section{References}

1. Nagasawa D, Yew A, Safaee M, Fong B, Gopen Q, Parsa AT, et al. Clinical characteristics and diagnostic imaging of epidermoid tumors. J Clin Neurosci 2011;18:1158-62.

2. Yildiz K, Sagir HÖ, Tosuner Z, Canter HI, Guneren E. Asymptomatic intradiploic epidermoid cyst eroding frontal bone in a patient with craniosynostosis. J Craniofac Surg 2015;26:e58-9.

3. Kuzeyli K, Duru S, Cakir E, Baykal S, Ceylan S, Aktürk F. Epidermoid tumor of the occipital bone. Neurosurg Rev 1996;19:109-12.

4. Guridi J, Ollier J, Aguilera F. Giant intradiploic epidermoid tumor of the occipital bone: Case report. Neurosurgery 1990;27:978-80.

5. Yamaguchi S, Hirohata T, Sumida M, Arita K, Kurisu K. Intradiploic arachnoid cyst identified by diffusion-weighted magnetic resonance imaging - Case report. Neurol Med Chir (Tokyo) 2002;42:137-9.

6. Garfinkle J, Melançon D, Cortes M, Tampieri D. Imaging pattern of calvarial lesions in adults. Skeletal Radiol 2011;40:1261-73.

7. Gadgil N, Humphries WE $3^{\text {rd }}$, Clay Goodman J, Gopinath SP. Hemorrhagic intradiploic epidermoid cyst. Clin Neurol Neurosurg 2013;115:2549-51.

8. Ormond DR, Omeis I, Abrahams J. Uncommon presentation of an intradiploic orbital epidermoid tumor: Case report. Oral Maxillofac Surg 2011;15:165-7.

9. Bretschneider T, Dorenbeck U, Strotzer M, Roth M, Rümmele P, Buettner R. Squamous cell carcinoma arising in an intradiploic epidermoid cyst. Neuroradiology 1999;41:570-2.

10. Hoeffel C, Heldt N, Chelle C, Claudon M, Hoeffel JC. Malignant change in an intradiploic epidermoid cyst. Acta Neurol Belg 1997;97:45-9.

This is an open access article distributed under the terms of the Creative Commons Attribution-NonCommercial-ShareAlike 3.0 License, which allows others to remix, tweak, and build upon the work non-commercially, as long as the author is credited and the new creations are licensed under the identical terms.

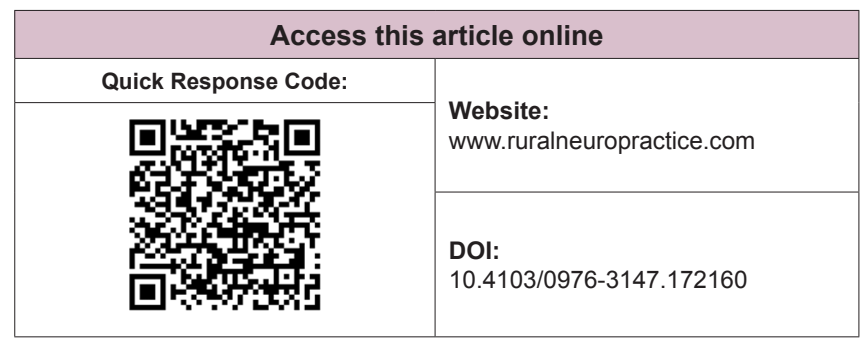

How to cite this article: Yilmaz B, Ekşi MŞ, Akakın A, KılıÇ T. A burning candle in the dark night-incidental intradiploic epidermoid cyst of occipital bone. J Neurosci Rural Pract 2016;7:181-2. 